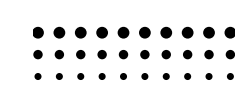

\title{
Old Habits Are Hard to Break
}

've heard it said that nothing lasts forever, and that was the
case with our campaign. Perhaps the most disappointing lesson of our experience-and one which is likely to be a fixture in any voting-rights activism done in our current climate-is that partisan posturing and litigation can tear apart a positive environment. In our case, it undermined the example we, to this day, continue to set for the rest of the country and other entities engaging in this work.

Importantly, we did not engage in scare tactics in order to get voter support for our constitutional amendment. We did not attack anyone or create an "enemy" to rally voters against. In fact, all we did was point to a broken system, and then appeal to people's sense of fairness while stoking feelings around forgiveness, restoration, and love. That's why when we saw over 5.1 million votes cast in support of our amendment, we knew they were votes not motivated by hate 
or fear. What we observed were votes based on love, forgiveness, and redemption. Election night demonstrated that love can in fact win the day, and that the people at the center of bringing such a diverse group of voters together were returning citizens; people who are traditionally viewed in a negative light or not given much thought. We showed the world that love is not only a force in personal relationships or times of tragedy, but also in movements to improve the lives of others and elections.

In addition to being able to move voters to act from love, our returning-citizen-led campaign created a dialogue around the expansion of democracy that was more about human decency and dignity, and less about partisanship. With pride, we were able to accomplish these feats in a political climate that was hyperpartisan and rife with divisive hate and fear. We ran a positive campaign that was the exception rather than the norm, and we had hopes of one day becoming the norm. Unfortunately, that would not be the case-even though positive, truthful, grassroots-led change is a standard that is (and should remain) the goal in democratic reform.

The infusion of politics and litigation quickly brought us back into the "business as usual" inertia. In Florida, we faced a Republican governor, speaker of the house, and senate president who insisted on getting involved in the implementation of Amendment 4, and on the other side were behemoth litigation/advocacy organizations. These huge and 
powerful forces always clash, bristling across sharp political lines, and we were right in the middle. What followed was a quick erosion of the world we had hoped to build. While we were still celebrating our amazing victory and the uniting of people, we couldn't avoid seeing trouble.

\section{The Aftermath of the Campaign}

$\mathrm{D}$ espite all we did to preempt challenges or opposition to our amendment; despite all of our attempts to keep our cause elevated about partisan politics, our predictions came true when Republicans in the state legislature took up Amendment 4 implementation in January, 2019-just two months after supermajority support from voters ensured its passage. Under the guise of "clarification," legislators introduced a bill that tried to alter the amendment's terms in ways that would have limited its impact.

The Florida legislature attempted to redefine key components of the amendment language. I likened this action to something that might happen to a (fictional) homeless family that is forced to live outside in the elements for several years. Every day, politicians walk past this family without ever offering assistance; without ever introducing and passing legislation to address the issues that keep them stuck on the street. Then one day, the community decides enough is enough; they come together and build the family a house. 
But as soon as the house is finished, the politicians demand that only they, the legislators, can determine how the house is furnished. Thus the Florida legislature decided that only they could determine, for instance, what constituted "completion of sentence," and that they knew best which crimes still should disqualify a returning citizen from re-enfranchisement under the law. For instance, because returning citizens who commit sexual offenses and murder are excluded from Amendment 4, various legislators now sought to expand those definitions: the new terms would include prostitution under "sexual offenses" and include attempted murder and manslaughter under "murder."

Additionally, the bill would also have mandated payment of court costs and fees to qualify for eligibility to vote. Amendment 4 already provided for completion of sentence, including restitution and fines associated with the conviction as part of eligibility; it did not, however, spell out those requirements in the language of the ballot measure. Therefore, in the Florida House of Representatives, there was an attempt to allow nonjudicial entities to expand the legal financial obligations beyond what was assessed at the time of sentencing. This meant that private entities like debt collection companies or other governmental agencies like the Florida Department of Corrections would be able to add more financial obligations such as cost of incarceration, or even outstanding medical fees, as a debt that must be settled before a person's sentence could be deemed complete. 
The FRRC and its allies fought back against these attempts. We argued that the legislature could not expand the definitions of "murder" or "sexual offense" to include the additional charges, and that "completion of sentence" should not be broadly defined to include legal financial obligations that were not punitive in nature. At the core of our efforts was the desire to minimize the number of returning citizens that would be excluded from the immediate benefits of Amendment 4. Each of the legislature's potential changes had the potential to impact tens of thousands of returning citizens.

We were not naive enough to believe that every single returning citizen was going to have immediate access to democracy. Florida definitely didn't have the type of appetite for expanding democracy to returning citizens as broadly as Maine or Vermont had. We knew that in addition to the returning citizens impacted by the "carve-outs," there would be some who owed restitution, which meant not having immediate access to democracy.

The House bill passed in April, but thankfully, many of the provisions about the expanded definition of a completed sentence didn't make it into law, because they were merged with the more moderate Senate bill. The Senate bill focused instead on restitution, fines, and fees. ${ }^{17}$ It would ultimately require returning citizens to pay all "court fees, fines and restitution" before they could vote. It also gave judges significant latitude to resolve outstanding charges, creating some 
opportunity for organizations like the FRRC to work with friendly judges, state attorneys, public defenders, and lawyers to expedite the process and qualify people to vote. However, the costs remain huge. In the last quarter of 2020, we raised over $\$ 23$ million to assist with newly returning citizens' fines and fees, and this amount could help only 44,000 people; there are still 700,000 returning citizens in Florida who need this help. This is dire math, and an enormous number of people who continue to wait for their voices to be heard in our democracy.

Yet it's important to mark one's victories. On January 9, 2019 , any amendment that passed during the previous election became officially a part of the state's constitution. So on that day, returning citizens across the state walked into the supervisor of election offices to register to vote. Throughout the state, they were greeted with confetti, balloons, and cheers. We were very intentional in touting January 9 as a day of love and celebration. We were intent on not letting the political pressure at the top dampen our spirits. We thought that January 9 was a great opportunity to do two things: amplify the message of love and become emissaries for democracy.

Every returning citizen who registered to vote was able to do so because love won the election. Each returning citizen had a family member or friend who loved them and believed in second chances, and because of that love, they voted yes on Amendment 4. Because of love, people like me now have 
a pathway to participating in democracy, and our first act was to register to vote.

It was not lost on us that as people who had lost our rights and fought hard to regain them, we now have a newfound appreciation for voting. It only made sense that we were the best emissaries to talk about how valuable that right to vote is, and how we honor it by becoming active participants in our democracy. We realized that we had an amazing opportunity to lead the charge to change the environment around voting; making voting something that people would aspire to do rather than regard as a chore. We wanted to make voting exciting again. Therefore, rather than harp on the negative political posturing, we chose to focus on people, and take whatever obstacle placed before us and turn it into opportunities to get even more people excited about democracy.

The excitement about participating in democracy was not just something we wanted to convey to returning citizens only. There were millions of people who were registered to vote but chose not to cast their ballot. There were also millions of people who were otherwise eligible to register to vote, but for some reason or another, had not done so. We wanted everyone to feel the passion for voting that we returning citizens had developed through losing our right to vote and then regaining it. Our democracy needs everyone to be involved in order for it to be vibrant. The people needed to be reminded of the passion we felt. 
We also knew that everyone also included politicians. They needed to understand that one of the keys to a vibrant democracy, and one of their responsibilities as elected officials, was encouraging and facilitating total involvement in elections. Conveying that message had been one of the hopes that drove our work.

If we want a vision of what this energy looks like, we could do little better than looking to the offices of elections supervisors. When I walked into these places, I was overcome with an overwhelming urge not just to vote, but to know everything about elections. These supervisors were constantly active in the community. Whether it was at a local high school, or at one of many community events in which they partnered with other grassroots organizations, these supervisors were wholeheartedly encouraging people to register to vote. They were providing all sorts of information about voting that demystified the process. They were doing everything to make the act of voting enticing instead of intimidating. That's why I wasn't surprised when several of these supervisors actually rolled out the red carpet and had balloons to welcome returning citizens as they filled out their voter registrations. These supervisors understood that the lifeblood of our democracy is participation.

Yet we were not sure that the politicians in our state capital understood this; nor those in other halls of power, too. It seemed then as it does now that many politicians lean toward making it more difficult for people to vote, and even making 
it more difficult for everyday citizens to engage in the citizens' initiative process. These were the very same people who had the power to dilute the effectiveness of Amendment 4, so with the victory behind us, there was no getting around dealing with the statehouse and the courts. There was no getting around dealing with the "politics."

The FRRC worked across partisan lines to improve the bill as much as possible and secure these changes. Given that Republicans vastly outnumber Democrats in both chambers and legislation was sure to pass, our strategy was to leverage bipartisan influence to ensure the least harmful outcome. We were not only trying to minimize any potential damage. We were also trying to infuse the spirit of Amendment 4 into the legislative process. We had just shown the state that we could move a major issue without attacking each other or tearing each other down. We had just demonstrated that Republicans and Democrats were willing and capable of coming together to agree on giving second chances to people with felony convictions. If the "people" can do it, then why can't our elected legislators do it as well? We took this question and many others into our conversations with politicians throughout the capital. We carried the message of the 5.1 million voters who said yes to Amendment 4, hopeful that our message would not fall on deaf ears.

We did not fully understand what we were up against. We did not realize that we placed ourselves right at the center of an age-old battle between politics and litigation; 
particularly between conservative politicians and progressive, litigation-based organizations, where the inevitable media engagement is a major driver of narrative.

Caught along with us were returning citizens who were taken on a rollercoaster ride of emotions, hope, and confusion. From the high of passing Amendment 4 to give 1.4 million returning citizens the right to vote, to the eventual low of the decision by the 11th Circuit Court of Appeals, which ruled that over 700,000 returning citizens would have to first pay any outstanding legal financial obligations before being able to register to vote, there was a series of ups and downs that dampened our message of excitement about democracy and made it more challenging to maintain the engagement of returning citizens.

\section{The Unintended Consequences of Litigation on Organizing}

\footnotetext{
nce Governor Rick DeSantis signed the bill into law that required returning citizens to satisfy their legal financial obligations prior to being able to register to vote, legal advocates led by the ACLU, the Brennan Center, and the Southern Poverty Law Center filed a suit challenging the legislation. While the move would earn some gains, those gains were limited, the process suffered because its separation from the grassroots, and media coverage instilled doubts in returning citizens.
} 
The lawsuit argued that Amendment 4 did not require fines and fees to be settled as a condition of rights restoration. It was filed on behalf of (only) seventeen plaintiffs who could be affected by the new law because they could not afford to pay their financial obligations. The plaintiffs likened these legal financial obligations to a "poll tax," and they requested that the court enjoin the new law, preventing it from taking effect statewide until the legal challenge is fully resolved.

In October 2019, US District Judge Robert Hinkle issued a limited ruling that the state could not use these plaintiffs' financial hardship as a reason to deny them their vote. He did not wade into the bigger questions around the "completion of sentence" language, or of the constitutionality of Amendment 4 that has since come under scrutiny as that was a question for Florida courts, not a federal one. Instead, the judge issued an injunction that allowed the plaintiffs to register to vote and actually participate in elections.

Judge Hinkle's decision also declared that legislators created an "administrative nightmare" with their laws implementing Amendment 4 and suggested that they should take action to address it rather than depending on the court. The criticism was merited, as this administrative barrier is indeed huge: the state established that legal obligations had to be paid, but it created no clear or centralized way to track fines or fees. In other words, it was not clear how returning citizens were to find out how much they had to pay, nor how exactly they were to go about paying it. All this only 
added to the confusion among impacted people who may be deterred from trying to register because they mistakenly believe they owe money. In addition, many unpaid court fees and fines multiply with time, so paying these costs creates a huge burden for many people who are already struggling through the reentry process. Governor DeSantis could take action to fix the state's antiquated clemency process to expedite restoration of voting rights to returning citizens with outstanding fines or fees, yet the leadership insists the state can take no action until the case is fully resolved, which could take years.

There was no quick path toward resolution, not when Republican lawmakers saw themselves as benefitting from keeping the issue tied up in the courts, and thereby keeping returning citizens out of the ballot box. Yet voting advocates declared the initial decision a victory, even though it did not apply to any of the 700,000 returning citizens except the seventeen plaintiffs. And as a result, those hundreds of thousands of returning citizens did not vote in the critical 2020 elections.

In the wake of lawsuits following a victory like this there are often hidden landmines. For instance, in a departure from past work on Amendment 4, the litigation strategy had not been coordinated with the FRRC or other groups representing returning citizens. The FRRC was not a plaintiff in the lawsuit. The FRRC also refrained from commenting on the politics that were playing out between the 
Florida GOP, the courts, and the legal advocacy groups who had taken up the cause.

Additionally, from the FRRC's perspective, the confusion and controversy created by the media coverage of these lawsuits had created what potentially could have become a greater impediment to progress than the actual legislation. Our challenge was magnified each day when votersalready disconnected from civic engagement-heard the persistent narrative that the Amendment 4 victory was moot because anyone with a fine or fee would not be able to vote or because the legislature circumvented the law with a new poll tax. Some experts had estimated that as many as 80 percent of returning citizens covered under Amendment 4 had some kind of financial obligation. Many would avoid registering to vote either because of their inability to pay or because of their uncertainty of whether they owed money and how much. Heightening their fear was the threat of prosecution because knowingly completing a voter registration card while being ineligible constitutes voter fraud-a crime in Florida.

In sum, it became clear that the legal tactics were absorbing much of the publicity around voting rights in Florida and increasingly reflecting the political polarization of the state. There was little consideration given to how the media coverage of these lawsuits would impact our efforts to reach returning citizens or to readily mobilize them to register to vote and engage in democracy. Meanwhile, legislators took 
advantage of the litigation to further polarize voters, while allowing our broken clemency system and problematic infrastructure limitations to persist.

So this is where things stand now: court challenges regarding this new law are slowly making their way through the system. We are hopeful that these challenges will be successful, but, in the meantime, many returning citizens are left in legal limbo. For now, our only alternative for helping these individuals is a county-by-county approach that enables smaller-scale activity based on local elected officials taking initiative to resolve fines and fees and register more people. This approach has some benefits, but also creates tremendous challenges with scale, resources, and impact in its aftermath.

\section{Organizing in the Aftermath}

$\mathbf{R}^{\text {ecause it is so important that this work harnesses a }}$ Bvision of positivity, the FRRC tried our best to overcome the rising pessimism that was infiltrating the movement. We presented an alternative view of the impact of the legislation by pointing out that even though there were over 700,000 returning citizens with outstanding legal financial obligations, Amendment 4 created a pathway for 1.4 million returning citizens; which meant that there were approximately 600,000 of us who did not have outstanding legal financial obligations and could register to vote immediately. 
In a state where presidential elections were decided by approximately 100,000 votes, adding so many new voters would mean that returning citizens could still be the deciding factor in local, state, and national elections.

Our message was very clear; in spite of the efforts to reduce the power of Amendment 4, the voices of returning citizens could not be completely silenced and there were more than enough of us to make a difference. We wanted to make sure that there was at least a glimmer of hope for returning citizens and for others who cared about democracy.

In addition to messaging, the FRRC designed several mechanisms to reengage returning citizens who are unable to register to vote because of remaining fines, fees, and restitution. While this program helps returning citizens ultimately be in a position to register to vote, it also provides another opportunity to engage with individuals who have been excluded from democracy, encouraging them to become involved with FRRC chapters and making it more likely that when they are able to register, they do so, and that when they are registered, they ultimately turn out to vote. Such a program could be a model to others. The initiative has three prongs:

1. Establish programs in judicial circuits in which there is an understanding among state attorneys, clerks of courts, public defenders, and judges to engage in an agreed-upon process that allows returning citizens to use the courts to 
waive their legal financial obligations for the purpose of establishing voter eligibility.

2. Create a crowd-sourcing apparatus to raise funds to help returning citizens satisfy their legal financial obligations.

3. Use all social media tools along with a bus tour to locate and engage returning citizens who are otherwise eligible to register to vote, and to continue to create an excitement around civic engagement.

The dampening effect on voter registration and returning citizen engagement was an unintended consequence of the battle between politicians and legal advocates, but it did not completely defeat our efforts. That's why on election night in 2020, before the votes were even officially counted, the FRRC celebrated yet again. We threw a lavish party with music, food, drinks, and revelry. When asked why, our answer was simple. We felt that in spite of the final outcome of the election, we had already won.

We were celebrating the fact that over 100,000 returning citizens had an opportunity to vote in the most critical election this country has ever seen, and for many of them, it was their first time ever voting in a presidential election. We celebrated the fact that returning citizens in their fifties, sixties, and seventies voted for the first time in their lives. We celebrated the fact that when combined with family members in the households of returning citizens, almost 300,000 people voted, many of whom had no prior expectations of voting, 
or had thought themselves to be a part of our democracy. We celebrated the fact that the trend was showing the 2020 election to have the greatest number of voters in the history of our country, even in the midst of a pandemic. While there were many reasons people could have chosen to not vote, the overwhelming number of them did. I impressed on reporters that regardless of the eventual outcome of the election, people should be celebrating the expansion of our democracy; more first-time voters, more youth voters, and an impressive showing of returning citizens voting.

Not all returning citizens voted the same way. The reality is that just like there is a diversity of directly impacted people, there is a diversity of voters who supported our effort. While we, of course, hoped returning citizens would vote a certain way on our issues, what was most important was that they had the opportunity to vote at all—and they did.

The Amendment 4 campaign presented a challenge of overcoming seemingly insurmountable odds. But they were not so formidable as to scare us off. And because we were able to achieve success with the referendum, we see the new challenges ahead as opportunities for the people who are most directly affected to lead the charge. We know how to run a campaign that deemphasizes politics and rebuffs the political urge to partisanize our efforts. In short, we believe that we can do it again. 